\title{
PENENTUAN SURFACE LOADING RATE (Vo) DAN WAKTU DETENSI (td) AIR BAKU AIR MINUM SUNGAI KREO DALAM PERENCANAAN PRASEDIMENTASI DAN SEDIMENTASI HR-WTP JATIBARANG
}

\author{
Ahmad Iman Tauhid; Wiharyanto Oktiawan; Ganjar Samudro \\ Departemen Teknik Lingkungan, Fakultas Teknik, Universitas Diponegoro, \\ Jl. Prof. H. Soedarto, SH, Tembalang, Semarang \\ Email :ahmadimantauhid@gmail.com
}

\begin{abstract}
Abstrak
Umumnya dalam pengolahan air, proses pemisahan padatan terjadi dalam bentuk pengendapan partikel diskrit (prasedimentasi atau grit chamber) dan pengendapan flokulan (sedimentasi). Sebelum melakukan perencanaan untuk mengolah air sungai Kreo, diperlukan analisa kecepatan pengendapan sebagai dasar kriteria desain yang akan digunakan dalam perencanaan bak prasedimentasi dan sedimentasi. Air sungai diambil sesuai dengan SNI 6989.57:5008 pada titik kordinat $X=429320, Y=9222982$, dalam zona 49 M. Sebelum melakukan analisa pengendapan, dilakukan Jar test untuk mengetahui dosis koagulan yang optimum. Didapatkan dosis koagulan yang optimum sebesar 20 mg/L. Hasil analisis didapatkan bahwa, dengan overflow rate sebesar 2,769 m/h, bak prasedimentasi dapat mengendapkan partikel dengan ukuran 0,0315 mm atau lebih besar. Untuk mencapai efisiensi $70 \%$ dalam pengolahan sedimentasi, maka dibutuhkan overflow rate (Vo) sebesar $1,3 \mathrm{~m} / \mathrm{h}$.
\end{abstract}

Kata kunci: sedimentasi, sungai Kreo, surface loading rate

\begin{abstract}
Generally, in water treatment, the solid separation process occurs in the form of discrete particle deposition (prasedimentation or grit chamber) and flocculant deposition (sedimentation). Before planning to process the Kreo river water, it is necessary to analyze the settling velocity as the basis of the design criteria that will be used in planning for sedimentation and sedimentation. River water is taken in accordance with SNI 6989.57: 5008 at the coordinate point X =429320, $Y=9222982$, in the zone of 49 M. Before performing the deposition analysis, a Jar test was performed to determine the optimum coagulant dose. Obtained an optimum coagulant dose of $20 \mathrm{mg} / \mathrm{L}$. The results of the analysis show that, with an overflow rate of $2,769 \mathrm{~m} / \mathrm{h}$, the pre-sedimentation bath can precipitate particles with a size of 0.0315 mm or greater. To achieve $70 \%$ efficiency in sedimentation processing, overflow rate (Vo) is needed at $1.3 \mathrm{~m} / \mathrm{h}$.
\end{abstract}

Keywords: Kreo river, sedimentation, surface loading rate

\section{PENDAhuluan}

Air sungai memiliki kandungan padatan yang cukup tinggi, sehingga tidak dapat langsung digunakan sebagai sumber air bersih. Selain itu dari segi parameterlain, air sungai perlu diolah secara kimiawi terlebih dahulu. Oleh karena itu, untuk dapat menggunakan air sungai, diperlukan adanya suatu pengolahan air baku menjadi air bersih/air minum dengan melihat kualitas air baku yang ada. Waduk Jatibarang sendiri memiliki potensi sebagai sumber air baku yang dapat digunakan, namun karena kualitas air baku yang belum layak dikonsumsi maka air baku perlu diolah lebih lanjut.

Proses pengolahan air minum umumnya terdiri dari pengadukan cepat, pengadukan lambat, pengendapan, dan filtrasi. Pengendapan (sedimentasi) adalah proses pemisahan padatan dari air 
menggunakan gravitasi. Sedimentasi terbagi menjadi 4 kelas; (1) pengendapan partikel diskrit, (2) pengendapan flokulan, (3) pengendapan terhambat, (4) pengendapan terkompres (Davis, 2010). Umumnya dalam pengolahan air, proses pemisahan padatan terjadi dalam bentuk pengendapan partikel diskrit (prasedimentasi atau grit chamber) dan pengendapan flokulan (sedimentasi) (Reynold, 1996).

Proses sedimentasi didasarkan pada pengendapan partikel secara gravitasi sehingga harus diketahui kecepatan pengendapan masing-masing partikel yang disisihkan. Proses sedimentasi dibagi dua klasifikasi grit chamber (Tipe 1) dan bak sedimentasi (Tipe 2). Kunci sedimentasi yang efisien tergantung pada beberapa parameter, yaitu tipe koagulan yang digunakan, kondisi pengadukan selama proses flokulasi dan materi koloid yang terkandung di dalam air baku (Kawamura, 1991).

Sedimentasi memiliki lebih dari satu aplikasi dalam pengolahan air. Tujuannya yang biasa dalam proses pengolahan konvensional adalah mengurangi beban padatan setelah koagulasi dan flokulasi. Aplikasi kedua, sebuah proses yang disebut plain sedimentation, adalah pengangkatan padatan dari sumber air keruh untuk mengurangi beban padatan pada proses instalasi pengolahan terutama berkaitan dengan pengendapan padatan flokulasi. Salah satu cara untuk merancang proses sedimentasi adalah memaksimalkan pemindahan zat padat, yang umumnya membutuhkan menurunkan surface loading clarifier, unit yang lebih besar dan lebih mahal. Pendekatan terakhir ini mengoptimalkan pada seluruh unit dan umumnya mengarah ke fasilitas yang lebih kecil dan lebih murah (AWWA, 2005).Pada dasarnya bak pengendapan yang panjang adalah yang paling baik tetapi tanpa didukung oleh faktor hidrolis lainnya seperti lamineritas dan uniformitas dari aliran dan beban permukaan yang sesuai, pengendapan dapat gagal (Darmasetiawan, 2001).

Peningkatan laju limpasan (overflow rate) di bak sedimentasi dan mencapai kualitas air yang sama atau lebih baik akan memungkinkan instalasi pengolahan air baru untuk dimuat di lokasi yang lebih kecil dan instalasi pengolahan air yang ada untuk diperluas tanpa harus menggunakan lahan tambahan. Sebagai contoh, tube settlerdapat dipasang di bak sedimentasi yang lama, secara signifikan meningkatkan laju pemuatan tangki tanpa menambahkan volume bak.

Pendekatan alternatif untuk sedimentasi, seperti sedimentasi tingkat tinggi menggunakan plate settler, tube settler, bak sedimentasi dengan aliran keatas, bak sedimentasi dengan selumut lumpur, dan ballasted sedimentation adalah salah satu teknologi untuk meningkatkan kapasitas bak sedimentasi (Crittenden et al., 2012).Oleh karena itu, analisa kecepatan pengendapan diperlukan sebagai dasar dalam perencanaan bak prasedimentasi dan sedimentasi untuk mengolah air sungai Kreo. 


\section{METODE PENELITIAN}

Penelitian dilakukan dengan estimasi pelaksanaan selama enam bulan, dimulai dari bulan April 2018 sampai September 2018. Lokasi air baku yang akan digunakan IPA adalah limpasan waduk Jatibarang yang mengalir menuju sungai Kreo di Kecamatan Gunungpati, Kota Semarang, Provinsi Jawa Tengah.

Air sungai diambil sesuai dengan SNI 6989.57:2008, sebanyak 60-80 liter, pada titik kordinat $\mathrm{X}=$ 429320, Y = 9222982, dalam zona 49 M. Sebelum mendisain sebuah bak final clarifier, maka perlu dilakukan percobaan laboratorium secara batch menggunakan column settling test.

1. Sebelum melakukan analisa pengendapan, dilakukan jar test untuk mengetahui dosis koagulan yang optimum. Jar test dilakukan berdasarkan SNI 19-6449-2000. Jar test menggunakan koagulan $\mathrm{PACl}$. PACl digunakan dalam perencanaan dikarenakan umum digunakan oleh PDAM, efisien dalam proses koagulasi, tidak sensitif $\mathrm{pH}$, dan memproduksi lumpur yang lebih sedikit. Dosis yang digunakan adalah sebesar $10 \mathrm{mg} / \mathrm{L}, 20 \mathrm{mg} / \mathrm{L}$, dan 30 mg/L. Air baku yang telah ditambahkan koagulan diaduk menggunakan mixer dengan kecepatan 210 rpm selama 30 detik dan 60 rpm selama 10 menit, kemudian didiamkan selama kurang lebih 15 menit.

2. Column settling test tipe 1 (gambar 1) bertujuan untuk menentukan nilai presentase removal partikel diskrit dan untuk memenentukan nilai kecepatan pengendapan partikel diskrit sebagai dasar penentuan dimensi bak prasedimentasi dan grit chamber. Air baku dimasukkan kedalam pipa setinggi $120 \mathrm{~cm}$ dengan lubang sampel pada kedalaman $90 \mathrm{~cm}$ (Pise dan Halkude, 2011). Pada rentang waktu 0,$5 ; 1 ; 2 ; 4 ; 8$ menit, sampel diambil dan diukur kekeruhannya (NTU). Hasil pengujian column settling tipe 1 berupa fraksi tersisa dan kecepatan pengendapan diplot untuk mengetahui diameter partikel diskrit yang mengendap.

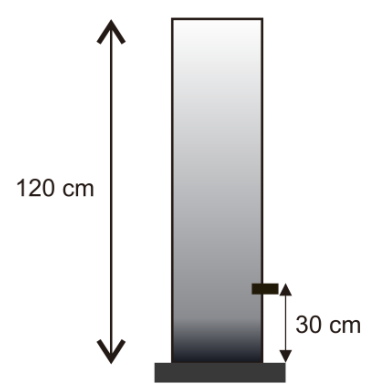

Gambar 1. Column settling tipe 1 
3. Column settling test tipe 2 (gambar 2) bertujuan untuk menentukan kecepatan pengendapan partikel flok sebagai dasar penentuan dimensi bak sedimentasi. Air baku dimasukkan kedalam pipa setinggi $120 \mathrm{~cm}$ dengan lubang sampel pada kedalaman 10;30;50;70;90 cm (Pise dan Halkude, 2011). Pada rentang waktu 10; 20; 30; 45; 60 menit, sampel diambil dan didapatkan nilai TSS (mg/L). Kedua tes dilakukan pada pipa dengan ukuran 4 inch. Hasil pengujian column settling tipe 2, berupa kadar TSS setiap interval waktu dan ketinggian diplot removal dan kecepatan pengendapan dalam bentuk grafik isoremoval. Dari grafik tersebut dapat diketahui hubungan anatara removal padatan dengan kecepatan pengendapan.

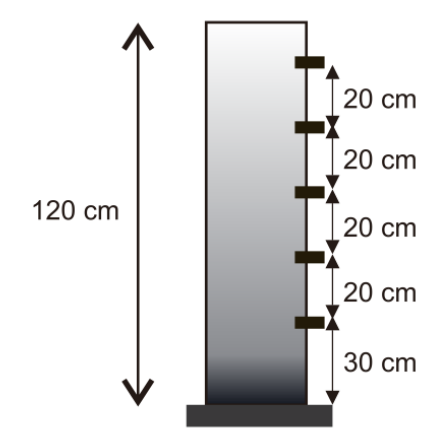

Gambar 2. Column settling tipe 2

\section{HASIL DAN PEMBAHASAN}

\subsection{JAR TEST}

Jar test dilakukan untuk mengetahui dosis koagulan. Dosis koagulan perlu ditentukan agar proses koagulasi-flokulasi-sedimentasi dapat berlangsung dengan baik. Poin 1 pada metode penelitian diketengahkan pada Tabel 1 mengenai nilai kekeruhan akhir dan \%removal kekeruhan.

Tabel 1. Hasil Jar Test

\begin{tabular}{lcccc}
\hline Dosis PACl & \multicolumn{3}{c}{ Kekeruhan (NTU) } & Kondisi Flok \\
& Awal & Akhir & \%Removal & \\
\hline $10 \mathrm{mg} / \mathrm{L}$ & & 0,73 & $87 \%$ & Cukup Baik \\
$20 \mathrm{mg} / \mathrm{L}$ & 5,68 & 0,39 & $93 \%$ & Baik \\
$30 \mathrm{mg} / \mathrm{L}$ & & 0,36 & $94 \%$ & Baik \\
\hline
\end{tabular}

Berdasarkan hasil jar test diatas, dosis yang mempunyai hasil kekeruhan paling bagus adalah 30 $\mathrm{mg} / \mathrm{L}$. Namun perbedaan kekeruhan antara dosis $20 \mathrm{mg} / \mathrm{L}$ dan $30 \mathrm{mg} / \mathrm{L}$ tidak terlalu besar, sehingga dipilih dosis $20 \mathrm{mg} / \mathrm{L}$.Besar dosis optimum yang dipilih sama dengan hasil penelitian oleh Margaretha 
et al. (2012), dimana air baku dengan kekeruhan 40-50 NTU dengan dosis PACl sebesar $20 \mathrm{mg} / \mathrm{L}$ mampu menurunkan kekeruhan sampai 2,73 NTU atau persen removal sebesar $94 \%$.

\subsection{COLUMN SETTLING TEST 1}

Column settling test 1 dilakukan untuk mengetahui beban pengendapan yang optimum untuk mengolah air baku menjadi air minum dalam kondisi sedimentasi 1 (pengendapan diskrit). Poin 2 pada metode penelitian diketengahkan pada Tabel 2 mengenai hasil pengamatanfraksi tersisa dengan kecepatan pengendapan. Poin 2 pada metode penelitian diketengahkan pada Gambar3 mengenai perbandingan fraksi tersisa dengan kecepatan pengendapan.

Tabel 2. Hasil Column Settling Tipe 1

\begin{tabular}{cccc}
\hline Lama Sampling & Kekeruhan & $\begin{array}{c}\text { Kecepatan Pengendapan } \\
\text { (Tinggi Reaktor/Lama } \\
\text { Sampling) } \\
\text { m/s }\end{array}$ & Fraksi Tersisa \\
\hline 0 & NTU & 0 & \% \\
0,5 & 6,28 & 0,03 & 100 \\
1 & 5,46 & 0,015 & 86,94 \\
2 & 5,13 & 0,0075 & 81,68 \\
4 & 5 & 0,00375 & 79,61 \\
8 & 4,97 & 0,001875 & 79,14 \\
\hline
\end{tabular}

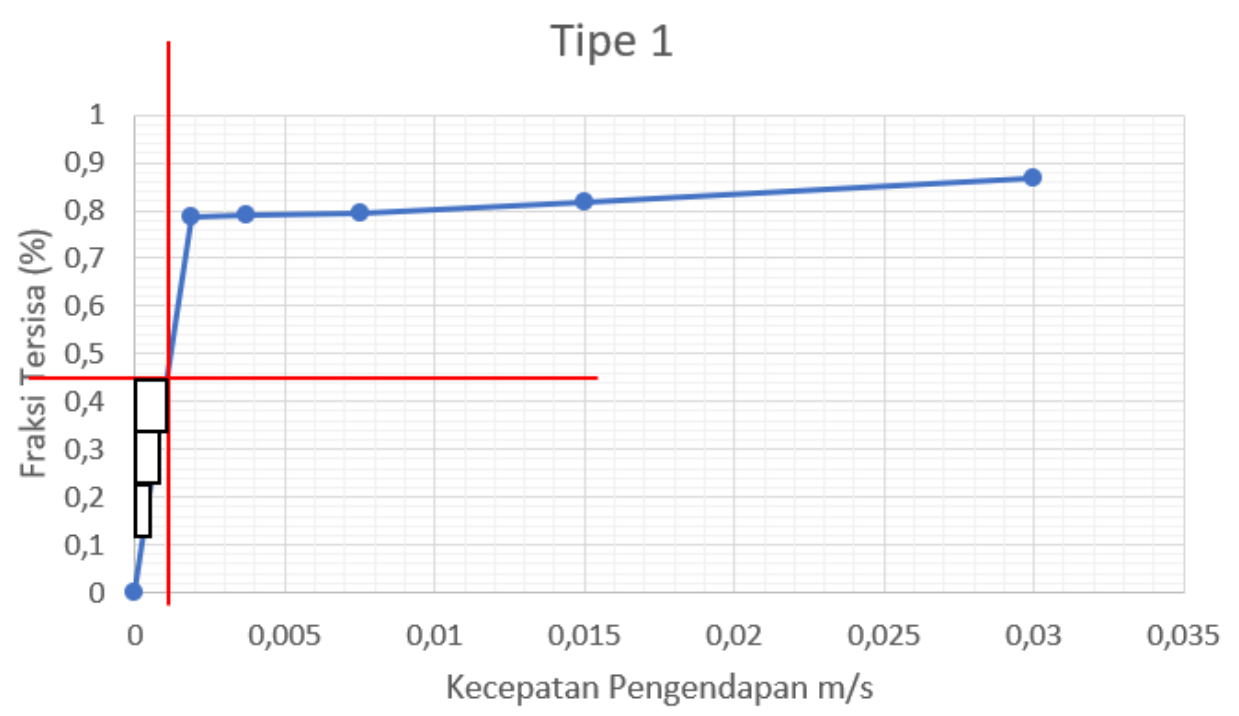

Gambar 3. Kurva Hubungan Fraksi Tersisa dengan Kecepatan Pengendapan 
Dari grafik pada gambar 3 dapat diketahui removal total dengan persamaan:

$\mathrm{F}_{\mathrm{o}}=0,46$

$\mathrm{V}_{\mathrm{o}}=0,001 \mathrm{~m} / \mathrm{s}$

$$
\begin{gathered}
\mathrm{R}=\left(1-\mathrm{F}_{\mathrm{o}}\right)+\frac{1}{\mathrm{~V}_{\mathrm{o}}} \int_{0}^{\mathrm{Fo}} \mathrm{Vdf}=(1-0,46)+\frac{1}{0,002} \times(0,00012) \\
\mathrm{R}=0,658=65,8 \%
\end{gathered}
$$

Menghitung diameter partikel:

$$
\begin{array}{ll}
\text { Vs } & =V o=\frac{\mathrm{g} \mathrm{D}^{2}\left(\mathrm{~s}_{\mathrm{g}}-1\right)}{18 \mathrm{v}} \\
0,001 & =\frac{9,81 \mathrm{D}^{2}(2,65-1)}{18 \times\left(0,893 \times 10^{-6}\right)} \\
\mathrm{D} & =0,0000315 \mathrm{~m}=0,0315 \mathrm{~mm}
\end{array}
$$

Cek bilangan Reynold:

$$
\text { Nre } \quad \begin{aligned}
& =(V s \times d p) / \mathrm{u} \\
& =(0,001 \times 0,0000315) /\left(0,893 \times 10^{-6}\right) \\
& =0,03527
\end{aligned}
$$

Nre yang didapatkan adalah kurang dari 1, maka hukum Stokes dapatdigunakan untuk menentukan kecepatan pengendapan pada kondisi aliranlaminar (Reynold, 1996).

$\mathrm{Cd}$

$$
\begin{aligned}
& =24 / \text { Nre } \\
& =24 /(0,03527) \\
& =680,38
\end{aligned}
$$

Setelah itu, gunakan koefisien drag (Cd) pada persamaan Newton untuk menentukan kecepatan pengendapan partikel

$$
\begin{array}{ll}
\mathrm{Vp} & =\sqrt{\frac{4 \mathrm{~g}}{3 \mathrm{Cd}}(\mathrm{Sg}-1) \mathrm{d}}=\sqrt{\frac{4(9,81)}{3(680,38)}(2,65-1) 0,0000315} \\
\mathrm{Vp} & =0,000999 \mathrm{~m} / \mathrm{s}
\end{array}
$$

Karenakecepatan pengendapan awal (Vo) yang diasumsikan 0,001 m/s hampir sama dengan kecepatan pengendapan awal (Vp) hasil perhitungan dengan hukum Stokes $=0,000999 \mathrm{~m} / \mathrm{s}$, maka iterasi kedua tidak perlu dihitung.Menurut ISO 14688-1:2017, partikel dengan diameter 0,0315 mm termasuk coarse silt, dimana lebih kecil dari diameter partikel $(0,1 \mathrm{~mm})$ yang perlu dicegah masuk ke dalam pompa menggunakan grit chamber (Kawamura, 1991).

Karena pengaruh eddy current, aliran udara, dan gangguanlainnya yang terjadi dan menghambat proses pengendapan di dalam air. Maka diberikan factor scale up (treatment parameter) pada grafik good performance sebesar 1,3 (Shammas, 2016). Hal ini terlihat pada gambar 4. 


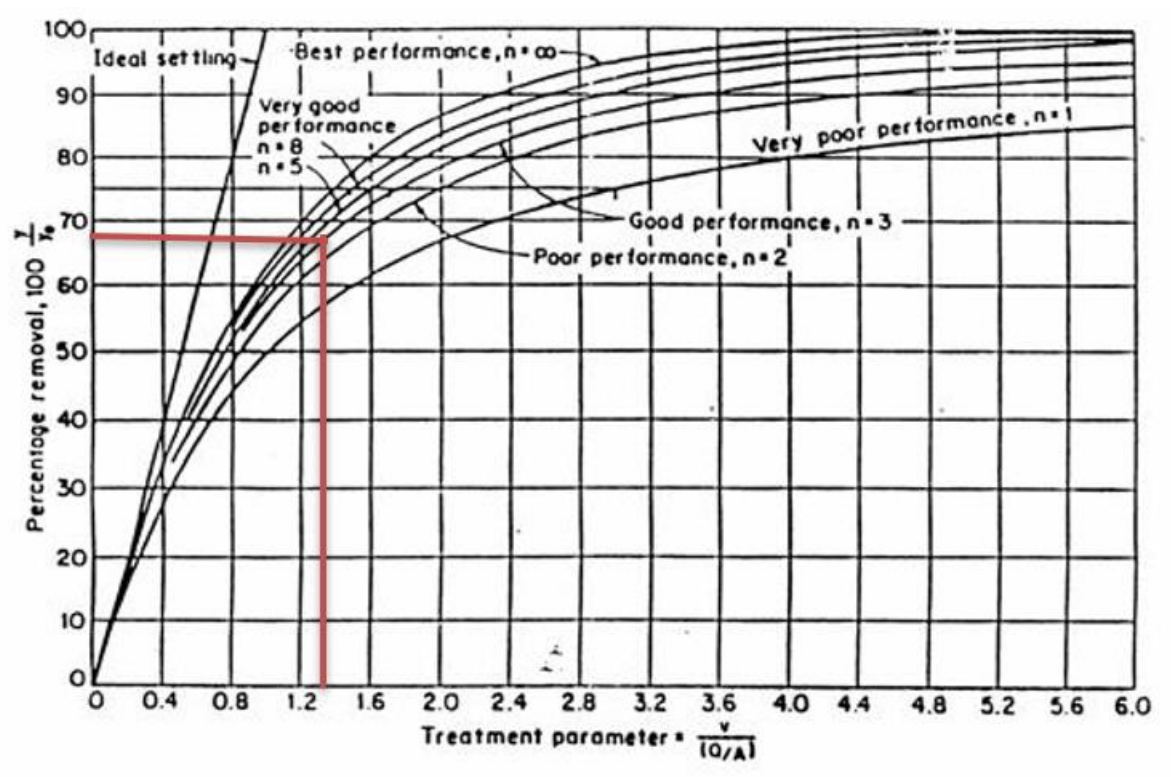

Gambar 4. Kurva Peformance

(Sumber: Shammas, 2016)

$\mathrm{Vs} /(\mathrm{Q} / \mathrm{A})$

$$
=1,3
$$

$0,001 /(\mathrm{Q} / \mathrm{A})$

$$
=1,3
$$

$\mathrm{Q} / \mathrm{A}$

$$
\begin{aligned}
& =\text { Overflow rate } \quad=0,000769 \mathrm{~m} / \mathrm{s} \\
& =2,769 \mathrm{~m} / \mathrm{h}
\end{aligned}
$$

Menghitung waktu tinggal:

Tinggi bak rencana $(\mathrm{H})=4 \mathrm{~m}$

$$
\mathrm{td}=\frac{\mathrm{H}}{\text { OverflowRate }}=\frac{4 \mathrm{~m}}{0,000769 \mathrm{~m} / \mathrm{s}} \times \frac{1 \text { menit }}{60 \mathrm{~s}}=86,67 \text { menit }
$$

Dari hasil perhitungan diatas didapatkan overflow rate (beban pengendapan) sebesar 2,769 m/h, dimana lebih kecil dari kriteria desain beban pengendapan menurut Crittenden (2012) dengan rentang beban pengendapan untuk sedimentasi dengan plate settler sebesar 8,3-16,67 m/h. Hal ini disebabkan karena kekeruhan air baku yang cukup rendah, sehingga tidak optimum jika diolah dengan unit prasedimentasi.

\subsection{COLUMN SETTLING TEST 2}

Column settling test 2 dilakukan untuk mengetahui beban pengendapan yang optimum untuk mengolah air baku yang telah diproses dengan koagulasi-flokulasi sehingga layak menjadi air minum dalam kondisi sedimentasi 2 (pengendapan flok). Poin 3 pada metode penelitian diketengahkan pada Tabel 3mengenai besarnya TSS, sedangkan pada Tabel 4 mengenai analisis removal TSS setiap satuan waktu dan ketinggian pengamatan. Poin 3 pada metode penelitian diketengahkan pada Gambar 
3 mengenai hubungan antara removal padatan dengan kecepatan pengendapan yang diplot dalam bentuk grafik isoremoval (gambar 5).

Tabel 3. Hasil Column Settling Tipe 2

\begin{tabular}{ccccccc}
\hline $\mathbf{H}$ & \multicolumn{7}{c}{ Waktu (menit) } \\
& $\mathbf{0}$ & $\mathbf{1 0}$ & $\mathbf{2 0}$ & $\mathbf{3 0}$ & $\mathbf{4 5}$ & $\mathbf{6 0}$ \\
$\mathbf{c m}$ & & \multicolumn{9}{c}{$\mathbf{~ m g / \mathbf { L }}$} \\
\hline 10 & 9,6 & 5,36 & 3,62 & 2,82 & 2,22 & 1,24 \\
30 & 9,6 & 5,96 & 3,80 & 3,31 & 2,25 & 1,62 \\
50 & 9,6 & 6,41 & 4,21 & 3,47 & 2,31 & 2,08 \\
70 & 9,6 & 6,70 & 4,74 & 3,72 & 2,36 & 2,26 \\
90 & 9,6 & 8,72 & 6,48 & 4,94 & 5,30 & 4,10 \\
\hline
\end{tabular}

Tabel 4. Persen Removal pada rentang waktu dan kedalaman tertentu

\begin{tabular}{ccccccc}
\hline $\mathbf{H}$ & $\mathbf{7}$ & \multicolumn{7}{c}{ Waktu (menit) } \\
$\mathrm{cm}$ & $\mathbf{0}$ & $\mathbf{1 0}$ & $\mathbf{2 0}$ & $\mathbf{3 0}$ & $\mathbf{4 5}$ & $\mathbf{6 0}$ \\
\hline 10 & - & 44 & 62 & 71 & 77 & 87 \\
30 & - & 38 & 60 & 66 & 77 & 83 \\
50 & - & 33 & 56 & 64 & 76 & 78 \\
70 & - & 30 & 51 & 61 & 75 & 76 \\
90 & - & $-*$ & $-*$ & $-*$ & $-*$ & $-*$ \\
\hline
\end{tabular}

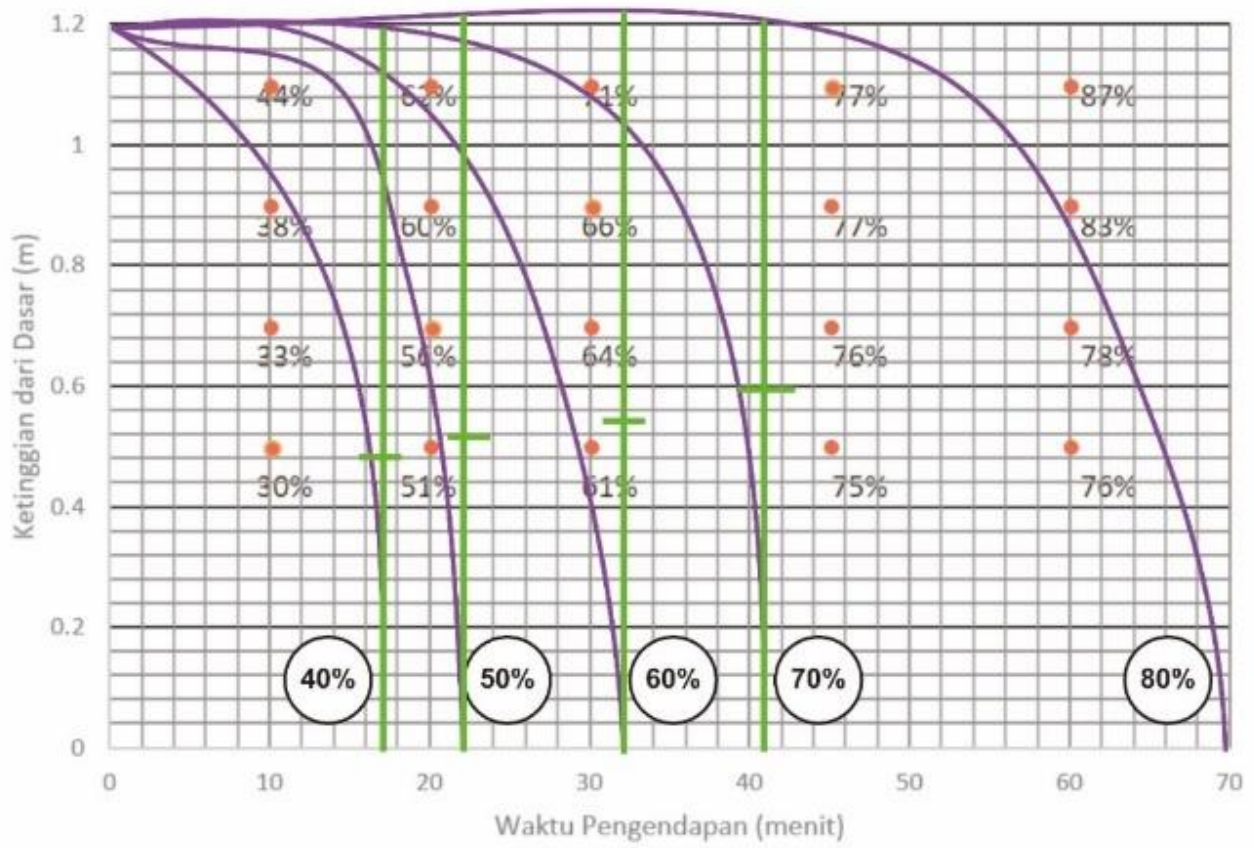

Gambar 5. Grafik Isoremoval 
Grafik isoremoval berakhir pada waktu 17, 22, 32, 41, 70 menit. Sebagai contoh, diambil waktu 22 menit, dapat dihitung removal total pada waktu tersebut adalah:

$$
\mathrm{Rt}=50+\frac{120-50}{120}(50-40)+\frac{120-110}{120}(60-50)+\frac{120-118}{120}(80-70)=56,83 \%
$$

Pada waktu 22 menit didapatkan surface loading rate sebesar:

$$
\mathrm{V}_{\mathrm{o}}=\frac{\mathrm{H}}{\mathrm{l}}=\frac{1,2 \mathrm{~m}}{22 \text { menit } \times \frac{1 \text { jam }}{60 \mathrm{menit}}}=4,24 \frac{\mathrm{m}}{\mathrm{h}}
$$

Berikut rekapitulasi hasil perhitungan:

Tabel 5. Hasil Perhitungan Overflow Rate

\begin{tabular}{cc}
\hline $\begin{array}{c}\text { Overflow Rate } \\
\mathbf{m} / \mathbf{h}\end{array}$ & $\begin{array}{c}\text { Removal Rate } \\
\mathbf{0}\end{array}$ \\
\hline 4,24 & 48,33 \\
3,27 & 56,83 \\
2,25 & 66,25 \\
1,76 & 75 \\
1,03 & 80 \\
\hline
\end{tabular}

Dapat dilihat dari gambar 6, untuk mencapai efisiensi 70\%, maka dibutuhkan overflow rate (Vo) sebesar 2 m/h. Dengan faktor scale down 0,65 (Reynold, 1996), didapatkan surface loading rate sebesar $1,3 \mathrm{~m} / \mathrm{h}$ atau $0,000361 \mathrm{~m} / \mathrm{s}$.

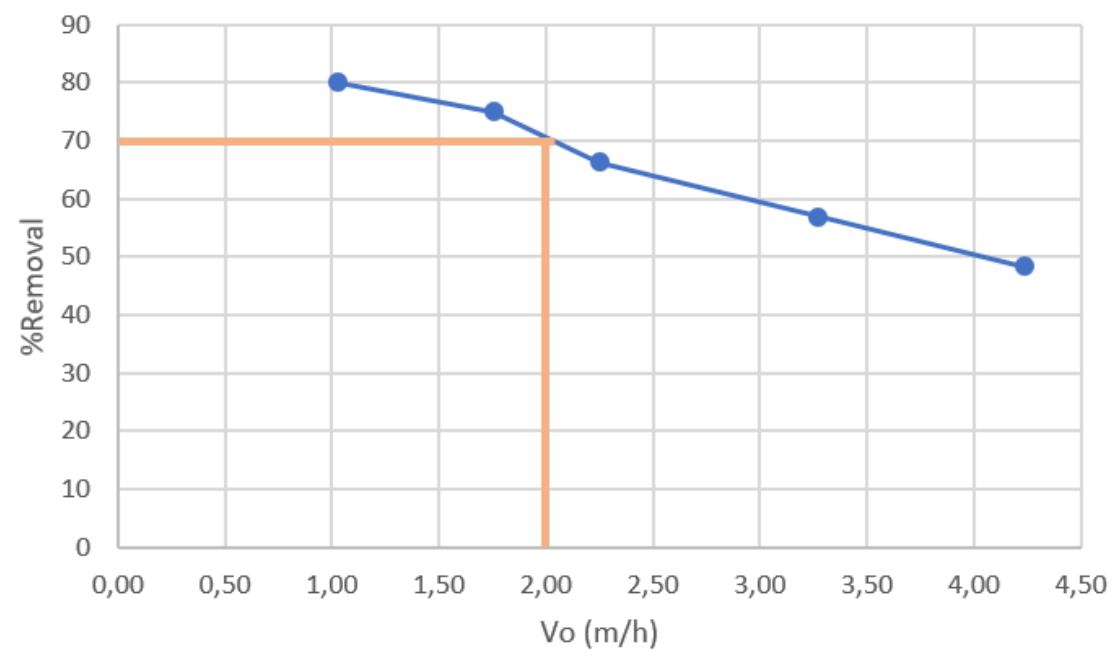

Gambar 6. Grafik Removal dan Overflow Rate 
Surface loading rate diatas dapat ditingkatkan dengan menggunakan plate settler tanpa mengurangi kualitas pengolahan. Berikut analisa secara matematis:

Jarak antar plate $(\mathrm{b}) \quad=0,1 \mathrm{~m}=10 \mathrm{~cm}$

Lebar plate $\quad=1,33 \mathrm{~m}$

Tinggi zona pengendapan $\quad=1,5 \mathrm{~m}$

Tinggi plate settler $(\mathrm{h}) \quad=\frac{\text { tinggi zona pengendapan }}{\sin \theta}=\frac{1,5 \mathrm{~m}}{\sin 60^{\circ}}=1,73 \mathrm{~m}$

Kemiringan plate $\quad=60^{\circ}$

Vo

$$
\begin{aligned}
& =V o^{\prime} \times \frac{\mathrm{W}}{\mathrm{H} \cos \vartheta+\mathrm{d} \sin \theta} \\
0,000361 & =\mathrm{Vo}^{\prime} \times \frac{0,1}{1,73 \cos 60^{\circ}+0,1 \sin 60^{\circ}} \\
\mathrm{Vo}^{\prime} & =0,004216 \mathrm{~m} / \mathrm{s}=12,36 \mathrm{~m} / \mathrm{h} \\
& =\frac{\mathrm{h}}{\mathrm{Vo}^{\prime}} \\
& =\frac{1,73 \mathrm{~m}}{12,36 \mathrm{~m} / \mathrm{h}}=0,1398 \mathrm{jam}=8,39 \text { menit }
\end{aligned}
$$

td modul $\quad=\frac{\mathrm{h}}{\mathrm{Vo}^{\prime}}$

Reduksi luas lahan $=\frac{(12,36-1,3) \mathrm{m} / \mathrm{h}}{12,36 \mathrm{~m} / \mathrm{h}} \times 100 \%=89,48 \%$

Menurut AWWA (2005), waktu detensi bukan parameter yang penting, sehingga beban pengendapan dijadikan sebagai acuan dalam mendesain suatu unit sedimentasi. Dari hasil perhitungan diatas didapatkan overflow rate (beban pengendapan) sebesar $12,36 \mathrm{~m} / \mathrm{h}$, dimana sudah sesuai dengan kriteria desain beban pengendapan menurut AWWA (2005) dengan rentang beban pengendapan untuk sedimentasi dengan plate settler sebesar 5-15 m/h.

\section{KESIMPULAN}

Dengan overflow rate sebesar $2,769 \mathrm{~m} / \mathrm{h}$ dan waktu tinggal sebesar 86,67 menit, bak prasedimentasi dapat mengendapkan partikel dengan ukuran 0,0315 $\mathrm{mm}$ atau lebih besar. Sedangkan untuk mencapai efisiensi 70\% dalam pengolahan koagulasi-flokulasi-sedimentasi, maka dibutuhkan overflow rate (Vo) sebesar $1,3 \mathrm{~m} / \mathrm{h}$ atau $0,000361 \mathrm{~m} / \mathrm{s}$. Namun, overflow rate dapat dapat ditingkatkan dengan menggunakan plate settler tanpa mengurangi kualitas pengolahan, maka didapatkan overflow rate (Vo) sebesar 12,36 $\mathrm{m} / \mathrm{h}$ dengan waktu tinggal pada modul sebesar 8,39 menit. 


\section{DAFTAR PUSTAKA}

[AWWA] American Water Works Association., (2005), Water Treatment Plant Design. Mc Graw Hill Company, New York, USA.

Crittenden, J., Rhodes, T., Tchobanoglous, G., (2012), MWH's Water Treatment Principle and Design. Mc Graw Hill Company, New Jersey, USA.

Darmasetiawan, M., (2001), Teori dan Perencanaan Instalasi Pengolahan Air, Yayasan Suryono, Bandung, Indonesia.

Davis, M., (2010), Water and Wastewater Engineering, Mc Graw Hill Company, New York, USA.

Kawamura, S., (1991), Integrated Design of Water Treatment Facilities. John Wiley \& Sons. New York, USA.

Margaretha, Mayasari, R., Syaiful, Subroto, (2012), Pengaruh Kualitas Air Baku Terhadap Dosis dan Biaya Aluminium Sulfat dan Poly Aluminium Chloride, Jurnal Teknik Kimia, 18, pp. 21-30.

Pise, C.P., Halkude, S.A., (2011), A modified method for settling column data analysis, International Journal of Engineering Science and Technology (IJEST), 3(4), pp. 3177-3183.

Reynold, T.D., (1996), Unit Operations in Environmental Engineering. Texas A \& M University, B/C Engineering Division Boston, Massachusetts, USA.

Shammas, N., (2016), Water Engineering. John Wiley and Sons Inc, New Jersey, USA.

SNI 19-6449-2000, Metode Pengujian Koagulasi - Flokulasi dengan Cara Jar Test.

SNI 6989.57:2008, Air dan air limbah - Bagian 57: Metoda pengambilan contoh air permukaan. 